\title{
THE POPULATION BIOLOGY OF THE BUTTERFLY, EUPHYDRYAS EDITHA. VIII. OVIPOSITION AND \\ ITS RELATION TO PATTERNS OF OVIPOSITION IN OTHER BUTTERFLIES ${ }^{1}$
}

\author{
Patricia A. Labine \\ Biomedical Data Processing Training Program, School of Public Health, \\ The University of Michigan, Ann Arbor, Michigan
}

Received December 15, 1967

This paper is one of a continuing series investigating the population biology of Euphydryas editha (Nymphalidae: Nymphalinae). The life history and general biology of this butterfly have been described in preceding papers that have dealt with aspects of its ecology, phenetics, and reproductive biology (Labine, 1964; Ehrlich, 1965; Ehrlich and Mason, 1966; Labine, 1966a; Mason, Ehrlich, and Emmel, 1967, 1968; Johnson, Keith, and Ehrlich, 1968).

The present paper is concerned with oviposition and its ecological consequences. "Oviposition" is used here in a broad sense and is meant to include oviposition behavior, egg number, egg size, rate of oviposition, etc. Attempts to interpret the oviposition pattern of Euphydryas editha led to comparisons with what is known of oviposition patterns in other butterflies.

\section{OVIPOSITION IN THE LABORATORY}

Methods used in maintaining ovipositing Euphydryas editha females in the laboratory have been described elsewhere (Labine, 1966a). The butterflies used in this study were collected as late instar larvae from the population in Woodside, California. Survival and fecundity values compiled from 53 females are presented in Table 1.

\footnotetext{
1 This work was supported in part by USPHS Training Grants No. 5T1 GM 892-06, and 5T01 GM 00365-05, and Grants GM-1430 and GB-5645 from the National Science Foundation. Present address: Dept. Biology, Williams College, Williamstown, Mass.
} Evolution 22:799-805. December, 1968

Similar data obtained from the literature and from personal communications for three other butterflies, Cercyonis oetus, Colias eurytheme, and Heliconius erato, are presented in Figures $1 b, 1 c$, and 1d. The size of each butterfly and the size of its egg are illustrated in the figures.

An estimate of the total number of eggs expected per female under laboratory conditions was calculated as the sum of the average number of eggs produced by females of age $x$, weighted by the proportion of adult females surviving to age $x$. This measure is somewhat analogous to the net reproductive rate, $R_{0}$, usually calculated from life table data, however, in our case only adult mortality is considered, and we are concerned with the total number of eggs, not just female eggs. These estimates are also noted in the figures. The value for Heliconius was not calculated, but taken directly from Crane (1955).

\section{Oviposition in Natural Populations}

Eleven complete oviposition sequences of wild Euphydryas editha females were observed in the Woodside population. One behavior pattern was consistently seen. The female would land in the ground cover, which in most parts of the colony was less than 6 inches high and consisted predominantly of the larval foodplant Plantago erecta. She would then "search" for a variable period of time, crawling through the ground cover, her wings slowly clapping together. Oviposition would begin once the female settled quietly and folded her wings. The sequence was always terminated by 

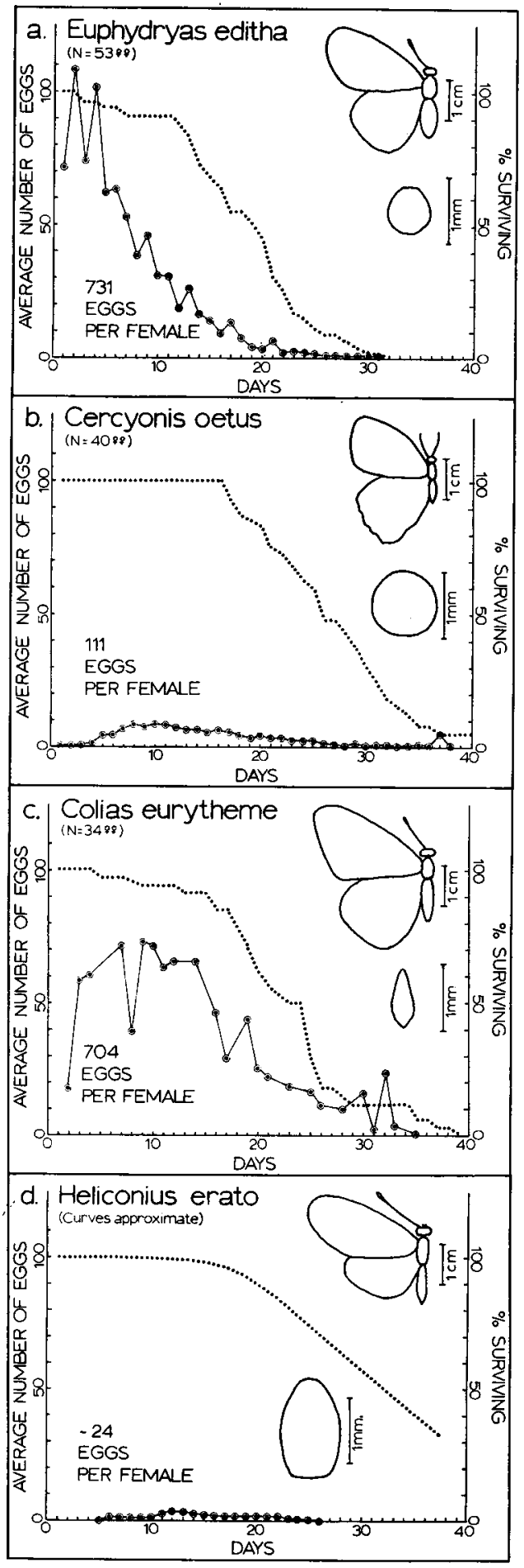

the female flying off abruptly. Mean duration ( \pm S.E.) of oviposition, starting from the time the female initially landed on the ground, was $29.7 \pm 2.8 \mathrm{~min}$.

Eggs were laid in clusters. In five instances the eggs were not placed on the foodplant, but on unidentified seedlings near Plantago plants. The mean size of eight clusters that were counted was $\mathbf{4 5 . 2}$ \pm 6.1 eggs (range: 75 to 21 eggs). This value is likely to be an underestimation of the true mean cluster size of Euphydryas editha. Females in the laboratory laid the largest clusters on the first few days of oviposition. The above field observations, with one exception, occurred late in the adult flight season which lasts approximately one month, and probably did not include the first large clutches of females. Oviposition sequences were observed on the following days, counting as day 1 the date of the first appearance of adults in the colony for that year: day $3,20,21,21$, $24,28,28,28$.

\section{Discussion}

The data presented above suggest that there are at least five components of variation in oviposition patterns of butterflies.

1) Number of eggs laid

2) Egg size

$$
\} \text { - Reproductive }
$$

Distribution

3) Onset of oviposition of reproduc-

4) Rate of oviposition - tive effort

5) Cluster size $\quad \begin{aligned} & \text { over space } \\ & \text { and time }\end{aligned}$

$\leftarrow$

FIG. 1. Survivorship and fecundity curves for laboratory populations. Dotted line $=$ survivorship; solid line $=$ fecundity. The scale of the drawings is indicated, and is the same for all figures. (a) Butterfly figure from Wright (1905); egg size, personal observation. (b) Data and egg size from Thomas Emmel (pers. comm.); butterfly figure from Seitz (1924). (c) Data from Stern and Smith (1960) and Ray F. Smith (pers. comm.); butterfly figure from Wright (1905); egg size from Edwards (1884) and Comstock (1927). (d) Data from Crane (1955); egg size from Beebe et al. (1960); butterfly figure is an approximation. 
TABLE 1. Survival and fecundity data compiled from 53 adult Euphydyras editha under laboratory conditions. Survival value at day $\mathrm{x}$ is the proportion of adult females surviving to age $\mathrm{x}$. Fecundity value at day $\mathrm{x}$ is the average number of eggs produced by a female of age $\mathrm{x}$.

\begin{tabular}{rrrrrr}
\hline \hline Day & Survival & Fecundity & Day & \multicolumn{2}{c}{ Survival Fecundity } \\
\hline 1 & 1.00 & 71.8 & 17 & 0.55 & 13.4 \\
2 & 1.00 & 108.6 & 18 & 0.55 & 7.2 \\
3 & 0.96 & 73.6 & 19 & 0.51 & 4.4 \\
4 & 0.96 & 101.4 & 20 & 0.45 & 3.8 \\
5 & 0.94 & 62.0 & 21 & 0.30 & 6.9 \\
6 & 0.94 & 63.3 & 22 & 0.25 & 2.2 \\
7 & 0.91 & 53.0 & 23 & 0.17 & 2.7 \\
8 & 0.91 & 38.7 & 24 & 0.15 & 2.1 \\
9 & 0.91 & 46.1 & 25 & 0.11 & 0 \\
10 & 0.91 & 30.9 & 26 & 0.09 & 0 \\
11 & 0.91 & 30.6 & 27 & 0.09 & 0 \\
12 & 0.87 & 18.6 & 28 & 0.06 & 2.0 \\
13 & 0.83 & 26.3 & 29 & 0.04 & 0 \\
14 & 0.72 & 16.1 & 30 & 0.02 & 0 \\
15 & 0.68 & 14.3 & 31 & 0.02 & 0 \\
16 & 0.64 & 9.5 & 32 & 0 & 0 \\
\hline
\end{tabular}

Each component will be discussed in turn, with attempts to demarcate the range of variation within the butterfly group, to locate the position of Euphydryas editha within this range, and, where such discussion may be profitable, to establish possible life history and ecological correlates of each component.

A brief description of the three other species represented in the figures will be helpful in comparisons of oviposition patterns.

Heliconius erato (Nymphalidae : Nymphalinae) is a neotropical butterfly showing great geographic variation (Emsley, 1964). The data used in this paper relate to the Trinidad form. $H$. erato is conspicuously colored and has been shown to be unpalatable to predators (Brower, Brower, and Collins, 1963). It is restrictive in its choice of larval foodplants, being associated only with species of Passiflora.

Colias eurytheme (Pieridae : Coliadinae), the alfalfa butterfly, is now common over most of North America, although it was once restricted to the western portion. It has become an economic pest in some areas. It hybridizes over most of its range with
Colias philodice, making the taxonomic status of some individuals uncertain. In the cooler areas of California, the source of the butterflies used for the oviposition data, the winter is passed by a dormant larval phase. In warmer areas Colias eurytheme has continuous generations.

Cercyonis oetus (Nymphalidae : Satyrinae) is part of a large, highly variable group of butterflies with uncertain taxonomic delineations. Cercyonis oetus ranges from the Pacific coast to the eastern edge of the Rockies. In Colorado, where the material used for the oviposition data was collected, it is a common butterfly of dry open grasslands (Brown, Eff, and Rotger, 1957). It is univoltine; the larvae begin winter diapause immediately upon hatching. The larval foodplants are grasses.

\section{Number of Eggs Laid}

Euphydryas editha lays the largest number of eggs (731 per female) of the four butterflies compared in the figures, although females of Colias eurytheme are within the same range with an expected number of 704. Some $E$. editha females lay as many as 1200 eggs. This is the largest number reported for any butterfly. One of the lowest reproductive rates among butterflies is that of the tropical Heliconius erato, Figure 1d, which lays only about 24 eggs per female.

A reproductive rate as large as that of $E$. editha allows an impressive power of increase. A few calculations quickly demonstrate this. Assume that $90 \%$ larval mortality is to be expected in natural populations, that there is a $1: 1$ sex ratio, and further assume that a single mated female founds a colony in a suitable area. In just the second season after this single founding event the population would have an expected size of over 2600 adults (2 . $\left.[(731 / 2) \cdot 0.10]^{2}=2672\right)$.

A high rate of increase is an important part of a good strategy for colonization; so is a strong cohesiveness of the population (MacArthur and Wilson, 1967). Remarkable inter-colony cohesion has been 
TABLE 2. Egg sizes and total egg-mass produced.

\begin{tabular}{lccc}
\hline \hline & $\begin{array}{c}\text { Egg size } \\
\left(\mathrm{mm}^{3}\right)\end{array}$ & $\begin{array}{c}\text { Eggs per } \\
\text { female }\end{array}$ & $\begin{array}{c}\text { Total egg } \\
\text { mass }\left(\mathrm{mm}^{3}\right)\end{array}$ \\
\hline Euphydryas editha & 0.17 & 731.0 & 124.3 \\
Cercyonis oetus & 0.52 & 111.4 & 57.9 \\
Colias eurytheme & 0.04 & 704.0 & 28.2 \\
Heliconius erato & 0.80 & $\sim 24$ & 19.2 \\
\hline
\end{tabular}

demonstrated for E. editha (Ehrlich, 1961). Both this characteristic, and its high rate of increase could relate to the fact that $E$. editha's habitat in the San Francisco Bay area is essentially insular, consisting of widely spread "islands" of serpentine outcroppings.

\section{Egg Size}

Egg sizes (volumes) of the four species compared were calculated by geometric approximations. These values are presented in Table 2. Among the values of the four species, the egg of $E$. editha occupies the second smallest position. The total range of variation among the eggs of these butterflies which have approximately the same body size is very large; a factor of 20 separates the largest from the smallest egg.

The product of egg size and egg number gives the volume of the egg mass expected per female, and this can be taken as an estimate of reproductive effort. This is a reasonable approximation with butterflies, although for animals showing parental care, the size of the egg mass must bear little relation to the total cost of reproduction.

One advantage of a small egg is obvious by comparison of the values of reproductive efforts in Table 2. Because of the size of its egg, Colias eurytheme attains a high reproductive rate (704 eggs per female) with a very small reproductive effort $\mathbf{( 2 8 . 2}$ $\mathrm{mm}^{3}$ ). A similar reproductive rate in Euphydryas editha is produced with an effort of $124.3 \mathrm{~mm}^{3}$.

Continual selection of genotypes leaving the greatest number of offspring should reduce egg size to some point where the advantage of a high reproductive rate is balanced by the disadvantages of a small egg and small hatching larvae. For example, a fibrous food plant may require that the mandibles of the larvae be of a certain size and strength, or a newly hatched larvae may have to be of a certain size to survive winter diapause. More information is needed to discuss the conditions determining egg sizes in butterflies. An investigation is in progress surveying variability of egg sizes and their distribution over foodplant and life history types.

One also needs more information to discuss determinants of reproductive effort. This area is one of active controversy (e.g., Skutch, 1967); however, there are certain simplifications in butterflies that should make the problem easier to attack. Since adults function mainly on reserves from feeding in the larval phase, the determining factors are best sought in the larval biology. The amount of time allotted to larval feeding (by life history pattern, by environmental conditions, etc.), the efficiency of larval feeding, and the availability of the foodplant must be significant determinants of the amount of energy expended on reproduction.

\section{Time of Initiation and Rate of Oviposition}

Females of Euphydryas editha emerge as heavy-bodied adults (they weigh about twice as much as newly emerged males) with large numbers of eggs already mature in their oviducts. The mean number ( \pm S.E.) of eggs present in one oviductthere are eight oviducts in all-in 58 newly emerged females was $140.9 \pm 18.5$. Of these, $25.1 \pm 1.4$ were fully mature eggs, judging by size and appearance. In other words, an average of 200 eggs out of a potential complement of approximately 1100 eggs are mature and ready for fertilization and oviposition when the female emerges. A necessary correlate of this pattern of egg maturation is an oviposition curve in which the greatest reproductive emphasis is placed upon the first few days of a female's life.

Colias eurytheme, over its adult life span, lays a total number of eggs similar to Euphydryas editha, but it emerges with all its eggs still immature, and several days 
must pass before oviposition can begin (Stern and Smith, 1960). Its oviposition curve is very different from that of Euphydryas editha (cf. Figs. 1a and 1c). Following the preoviposition period, the oviposition rate rapidly builds to a maximum and is maintained at this level for over a week.

The oviposition curve of Cercyonis oetus (Fig. 1b), although reduced in magnitude, is similar to that of Colias eurytheme, and presumably reflects a similar pattern of egg maturation.

There is little additional information in the literature on the timing of oviposition in butterflies. Magnus (1953) reports that for Argynnis paphia, an Old World fritillary, 8 to 10 days are required for a female to mature before she will mate. Oviposition then begins a day or so later (Magnus, 1950). The white admiral, Limenitis camilla, mates soon after emergence, but oviposition is delayed 3 days (Lederer, 1960).

Immediate oviposition after emergence does have important advantages, although it is obviously not universally used by butterflies. There are certain ancillary conditions to the oviposition pattern of Euphydryas editha which may suggest why more butterflies do not exploit these advantages. The newly emerged Euphydryas editha female is heavy with eggs, and hence her participation in any search for mates is restricted. Yet the female must mate soon after emergence if there is to be any advantage gained by the early maturation of large numbers of eggs. Most matings in Euphydryas editha are initiated by males that sight females as they rest in the ground cover (Labine, 1966b). This means of mate discovery suffices only because $E$. editha maintains localized populations of high density in which the probability of any female being discovered is quite high. For butterflies not restricted to dense localized colonies, a more active role by the female must be required to bring about mate encounters, and this probably prohibits a heavy female laden with already mature eggs.

It is interesting that many moths have oviposition patterns similar to Euphydryas editha, with the emerged females heavy with eggs and restricted in mobility; but their efficient assembling devices eliminate any concomitant dependency upon high population densities for mate discovery.

It is still difficult to explain why some butterflies, e.g., Heliconius erato, wait more than just a few days before beginning oviposition. An interesting hypothesis is that for these species, feeding by the adult may be necessary to furnish energy for egg production. Unlike the situation in Euphydryas editha and similar species, larval feeding in these butterflies may not provide the full cost of reproduction. This may relate to a limited supply of suitable larval foodplant, or to a foodplant of limited nutritional value. It may be the result of a short larval period, shortened in response to heavy larval mortality by forces to which other phases of the life history are immune.

\section{Cluster Size}

Euphydryas editha lays its eggs in large clusters. Three other Euphydryas species, E. phaeton (Clark, 1928), E. aurinia (Ford, 1962 ), and $E$. chalcedona (personal observation) also lay eggs in clusters of 50 or more.

Most butterflies, however, deposit their eggs singly. This is true for Colias eurytheme (Stern and Smith, 1960), Heliconius erato (Beebe et al., 1960), and probably also true for Cercyonis oetus. Of all the British butterflies (about 60 species excluding skippers), Ford (1962) reports that only nine oviposit eggs in large clusters. Seven of these are Nymphalids: Melitaea cinxia, M. athalia, Euphydryas aurina, Nymphalis antiopa, $N$. io, $N$. polychloros, and Aglais urticae. Two are Pierids: Pieris brassicae and Aporia crataegi. Two other British species lay eggs in clusters of 5 to 15: one Lycaenid, Hamearis lucina, and one Pierid, Pieris rapae. Clark and Dickson (1952) have described the life histories of 38 South African species and report that of these only two oviposit in clusters: 
Acraea horta (Nymphalidae) and Belenois aurota (Pieridae).

A preliminary survey of the literature has found reference to 10 other butterflies which oviposit in clusters of several eggs or more. Eight are Nymphalids: Chlosyne (Melitaea) harrisii (Dethier, 1959), C. hoffmanni (Newcomer, 1967), Asterocampa celtis (Scudder, 1889), Dione juno, Heliconius doris, $H$. wallacei, $H$. sara, $H$. ricini (Beebe et al., 1960). Two are Lycaenids: Eumaeus debora, E. minyas (Ross, 1964).

Is there any pattern in the tendency to cluster eggs at one oviposition site? There seems to be at least a taxonomic regularity. The subfamily Nymphalinae is disproportionately represented among butterflies that cluster their eggs. Of the 26 species listed above, 18 are members of this subfamily.

Most instances of egg clustering seem to be associated with the type of larval defenses against predators that can be intensified by aggregations of larvae. These include spinning a sheltering web, emitting offensive odors, showing warning patterns, etc. (see Ford, 1962:89).

The Euphydryas species E. editha, $E$. aurinia, and $E$. phaeton, spin communal larval webs. The webs of the early instars of $E$. editha are much more evident in laboratory broods than in the field; however, the latter two species build very structured webs in nature. In addition, the larvae of all three species show a synchronized behavior pattern when disturbed. They will stop and together snap their heads up several times in succession. Edwards (Vol. II, 1884) has observed this behavior elicited in $E$. phaeton by an ichneumon parasite. In populations of $E$. editha, braconid parasites can cause heavy larval mortality (Ehrlich, 1965).

It is interesting to note that clustering of eggs will result in a tendency for the young to die or survive together as a brood. This will increase the variance of the number of surviving offspring per female and this in turn can considerably reduce $N_{e}$, the effective population size (Crow and Morton, 1955).

\section{SUMMARY}

The oviposition pattern of Euphydryas editha is described and compared with the oviposition patterns of Cercyonis oetus, Colias eurytheme, and Heliconius erato. Five components of variation in the oviposition patterns of butterflies are discussed: (1) Number of eggs laid, (2) Egg size, (3) Onset of oviposition, (4) Rate of oviposition, (5) Cluster size. Ecological and life history correlates of these components are suggested.

\section{Literature Cited}

Beebe, W., J. Crane, and H. Fleming. 1960. A comparison of eggs, larvae, and pupae in fourteen species of Heliconiine butterflies from Trinidad, W. I. Zoologica 45:111-154.

Brower, L. P., J. VZ. Brower, aNd C. T. ColLINS. 1963. Experimental studies of mimicry. 7. Relative palatability and Mullerian mimicry among neotropical butterflies of the subfamily Heliconiinae. Zoologica 48:65-84.

Brown, F. M., D. EFF, AND B. Rotger. 1957. Colorado butterflies. Denver Museum of Natural History, Denver, Colo.

Clark, A. H. 1928. Notes on the melitaeid butterfly, Euphydryas phaeton with a description of a new subspecies and a new variety. U. S. Nat. Hist. Mus. Proc. 71 (Article 11).

Clark, G. C., and C. G. C. Dickson. 1952. Some South African butterflies. Longmans Green and Co., Cape Town.

Comstock, J. A. 1927. Butterflies of California. Published by the author, Los Angeles, California.

CRANE, J. 1955. Imaginal behavior of a Trinidad butterfly, Heliconius erato hydara Hewitson, with special reference to the social use of color. Zoologica 40:167-196.

Crow, J. F., AND N. E. Morton. 1955. Measurements of gene frequency in small populations. Evolution 9:202-214.

Dethier, V. G. 1959. Food-plant distribution and density and larval dispersal as factors affecting insect populations. Canadian Entomologist 91:581-596.

EDwards, W. H. 1884. The butterflies of North America. Houghton, Mifflin and Co., Boston.

EHRLICH, P. R. 1961. Intrinsic barriers to dispersal in checkerspot butterfly. Science 134: 108-109.

- 1965. Population biology of the butterfly, Euphydryas editha. II. Structure of the Jasper Ridge Colony. Evolution 19:327-336.

Ehrlich, P. R., and L. G. Mason. 1966. Population biology of the butterfly, Euphydryas 
editha. III. Selection and the phenetics of the Jasper Ridge Colony. Evolution 20:165-173.

Emsiey, M. G. 1964. The geographical distribution of the color-pattern components of Heliconius erato and Heliconius melpomene with genetical evidence for the systematic relationship between the two species. Zoologica 49:245-286.

Ford, E. B. 1962. Butterflies. Collins, London.

Johnson, M., A. KeTtH, AND P. R. EhrLICH. 1968. Population biology of the butterfly Euphydryas editha. VII. Has $E$. editha evolved a serpentine race? Evolution 22:422-423.

Labine, P. A. 1964. Population biology of the butterfly, Euphydryas editha. I. Barriers to multiple inseminations. Evolution 18:335-336.

—. 1966a. Population biology of the butterfly, Euphydryas editha. IV. Sperm precedence-a preliminary report. Evolution 20: $580-586$.

- 1966b. The reproductive biology of the checkerspot butterfly, Euphydryas editha. Ph.D. Thesis, Stanford University.

LEDERER, G. 1960 . Verhaltensweisen der Imagines und der Entwicklungsstadien von Limenitis camilla camilla L. (Lep., Nymphalidae). Zeit. fur Tierpsych. 17:521-546.

MacArthur, R. H., aNd E. O. WILson. 1967. The theory of island biogeography. Princeton University Press, Princeton.

Magnus, D. 1950. Beobachtungen zur Balz und Eiablage des Kaisermantels Argynnis paphia L. (Lep., Nymphalidae). Zeit. fur Tierpsych. 7: 435-449.
- 1953. Methodik und Ergebnisse einer Populationsmarkierung des Kaisermantels. Verh. dtsh. Entomol. 1953:187-197.

Mason, L. G., P. R. Ehruich, and T. C. EMmed. 1967. The population biology of the butterfly, Euphydryas editha. V. Character clusters and asymmetry. Evolution 21:85-91.

- 1968. The population biology of the butterfly, Euphydryas editha. VI. Phenetics of the Jasper Ridge Colony, 1965-1966. Evolution 22:46-54.

Newcomer, E. J. 1967. Early stages of Chlosyne hoffmanni manchada (Nymphalidae). J. Lepid. Soc. 21:71-73.

Ross, G. N. 1964. Life history studies on Mexican butterflies. III. Nine Rhopalocera from Ocotal Chico, Veracruz. J. Res. Lepid. 3:207-229.

Scudder, S. H. 1889. The butterflies of the eastern United States and Canada with special reference to New England. Cambridge, Mass.

Seirz, A. 1924. The American Rhopalocera. Alfred Kernen, Stuttgart.

Skutch, A. F, 1967. Adaptive limitation of the reproductive rate of birds. Ibis 109:579-599.

Stern, V. M., AND R. F. SMIth. 1960. Factors affecting egg production and oviposition in populations of Colias philodice eurytheme Boisduval (Lepidoptera : Pieridae). Hilgardia 29:411-454.

Wright, W. G. 1905. Butterflies of the West Coast of the United States. Whitaker and Ray Co., San Francisco. 